Your revised manuscript entitled "Transforming marginalised adult learners' views themselves: Access courses in England" has been accepted for publication in the Special Issue on "Educational Inclusion" which is due to be published in Volume 35 2014. Professor David James, Chair of Executive Editorial Board, British Journal of Sociology of Education

\title{
Transforming marginalised adult learners' views themselves: Access to Higher Education courses in England
}

Hugh Busher, Nalita James, Anna Piela, Anna-Marie Palmer

University of Leicester, UK

\section{*Corresponding Author:}

Hugh Busher, School of Education, University of Leicester, 21 University Road, Leicester, LE 17 RF, UK. t: +44(0)1162523688; e: hugh.busher@le.ac.uk 


\title{
Transforming marginalised adult learners' views themselves: Access courses in England
}

\author{
Abstract \\ Adult learners on Access to Higher Education courses struggled with institutional and social \\ structures to attend their courses, but transformed their identities as learners through \\ them. Although asymmetrical power relationships dominated the intentional learning \\ communities of their courses, their work was facilitated by collaborative cultures and \\ supportive tutors, and students gained the confidence to construct their own emergent \\ communities of practice for learning. The students attended seven FE Colleges in the East \\ Midlands of England. Data was collected by mixed methods within a social constructivist \\ framework from students and their tutors.
}

Keywords: Widening participation, marginalisation, Adult education, power, socio-political contexts

\section{Introduction}

People's identities are always shifting (Bauman, 2000) but do so especially when they encounter new or challenging situations as liminal spaces (Bhabha, 1994). The project of self-development is never ending (Giddens, 1991). One group of people who experience particularly challenging circumstances are mature students on Access to Higher Education (HE) courses who return to formal education to enhance their cultural capital (Bourdieu, 1990) and engage in a process of (re)construction and on-going development (Brine and Waller, 2004) of their identities as learners. Like other non-traditional learners, they are often initially tentative about this as their previous life experiences have frequently given them little confidence for engaging in formal learning (Crossan et al., 2003). They lack confidence that their habitus (Bourdieu, 1990) will allow them to assert and develop their agency successfully in the field of formal learning in Further Education (FE) Colleges, where Access to HE courses are conventionally located. They fear their learning experiences will be riven with tensions between them as agents, others, and the social and institutional structures they encounter (O'Donnell and Tobbell, 2007). FE Colleges are the main educational institutions in England and Wales for 'providing opportunities for lifelong learning, and ... promoting economic growth and social cohesion' (Jephcote et al., 2008: 164). They tend to offer a collaborative ethos or culture focused around values celebrating mature learners (Warmington, 2002).

In England and Wales, Access to HE courses, originally established in the 1970s, are for those 'excluded, delayed or otherwise deterred by a need to qualify for (university) entry in more conventional ways' (Parry, 1996: 11). Currently they recruit about 40,000 adults a year 
(QAA, 2013) and are a major element in reducing educational disadvantage (Jones, 2006: 485) and widening participation in HE. They are intended to provide adult learners (aged 19 years or older) with the subject knowledge and generic skills required for progression to and effective study at university. They lead to a diploma that is awarded by regional award validating authorities (AVAs) which are regulated by the Quality Assurance Agency (QAA) on behalf of central government in England and Wales. The courses are usually offered through a variety of subject focused pathways such as Nursing and midwifery, Social Sciences, or Business studies.

Government education policy in England and Wales, like that in the European Union, aims to widen participation in Higher Education (HE) to satisfy the need of European economies for high-skilled labour (Field et al., 2010) in a global market. However, widening participation is a contested notion linked in part to social justice and equality of opportunity and in part to strengthening economic prosperity both for individuals and nationally (Burke, 2007). Recently, in England and Wales it has been redefined as 'fair access' to HE through the development of particular admissions practices by HE institutions (BIS, 2012: 4), rather than as free access for those people from marginalised social groups traditionally underrepresented in HE. Further, since 2012, central government has encouraged Access to HE course providers to target younger people. Now only young adults aged 19-24 years undertaking their first full level 2 (equivalent to GCSE, the school leaving examination in England) or level 3 qualification (equivalent to ' $A$ ' level or Access to HE courses in England and Wales) will be fully funded (BIS, 2010). Other older students will only be able to access government backed loans to fund their Level 3 courses (BIS, 2010). This new funding regime is likely to inhibit older people in financially straitened circumstances because of family commitments and /or lower paid employment from applying for Access to HE courses.

This paper considers how Access to HE students pursued the project of the self (Giddens, 1991) in order to enhance their cultural capital (Bourdieu, 1990), and how these projects are shaped by their struggles as citizens in the particular socio-economic policy contexts (Foucault, 1977) since 2010, by their power-invested relationships (Handley et al., 2006) with their tutors and by their interactions with their colleagues on Access to HE courses which, possibly, generate communities of practice (Wenger, 1998).

\section{Transforming identities in the particular institutional contexts}

People construct their work-related identities and values from their shared experiences with others in multiple communities (Wenger, 1998, Holliday, 1999), and from the dispositions of knowledge, skills, values and experiences they carry with them, their histories (Kearney, 2003). People's identities develop throughout their lives (Bauman, 2000) through the interplay between individual agency and identity, institutional structures and social circumstances (Wyn and White, 1998), including their families and friends through whom they develop social capital (Bourdieu 1990) and acquire an habitus (Bourdieu 1990). People's identities are the means by which they position themselves within a society or a community (Benjamin, 2002) and shape their interactions with others, as well as being a persona or mask that allows them to play parts ascribed to them in a community (Hollis, 1985). 
For students on Access to HE courses their identities play out in various arena such as the local socio-economic and community contexts, the curriculum contexts of the Access to HE diploma and the institutional contexts of FE colleges which host these courses. The institutional context includes the classrooms where they encounter their tutors, college policies, teaching and learning practices, college cultures and course sub-cultures. It involves moral and a political activity that constitute the managing, monitoring and resolving of value conflicts, where values are defined as concepts of the desirable (Hodgkinson, 1999). Resolving these conflicts ethically and transparently in keeping with previously established social and moral norms in an institution or community leads to greater social cohesion (MacBeath and MacDonald 2000) by constructing shared narratives or cultures. These define the core practices, values and boundaries in and of a community (Wenger, 1998), such as a teaching group or institution, which occur in particular places / spaces at certain times.

Changing uses and demarcations of space through time reflect the changing relationships of people to each other and to the institution in which they are located (Paechter, 2004). How people colonise the physical, online and organisational spaces they occupy, whether or not formally allocated to them by an institution, are part of the discourses about how they are constrained but try to assert their agency individually and collectively (Foucault, 1976 in Gordon 1980) to construct the cultures of their work groups or communities within broader constellations of cultures (Wenger, 1998, Holliday, 1999) or institutions. In these spaces, organisational cultures, intertwined with power relationships are negotiated by members of institutions to reflect and guide the values, relationships and practices that lie at the core of communities and institutions (Wenger, 1998) in particular socio-political contexts.

A community's culture represent a nexus of particular values and beliefs which help members to have a collective work-related identity that encompass subtle cultural dynamics such as members' perceived social functions and assumptions, rule-making, behavioural norms, and boundary and periphery definitions (Wenger 1998:117), as well as articulated and unarticulated cues about members' status in a particular community. Cultures are constructed for a whole organisation like an FE college, as well as for communities or departments within it. While some authors (Senge, 2006, MacGilchrist et al., 2004) perceive the cultures of communities within institutions, e.g. departments, as subcultures, emphasising the hierarchical institutional process of culture construction, Holliday (1999) describes them as small cultures to emphasise the agentic nature of culture construction that also draws on the socio-political contexts that community members inhabit. However, cultures are not fixed but shift (Holliday et al., 2010) as membership of communities shift and as the social and policy contexts of those communities shift.

Whilst it is difficult to be prescriptive about what cultures in teaching and learning might be preferred, values and practices that sustain trust and collaboration between participants are likely to lead to a critical dialogue about the repertoire of teaching and learning practices (Smyth et al., 2000) which will enhance the conduct of participants' enterprise (Wenger, 1998) by giving them a sense of ownership of it. Supportive learning cultures, which included informal support structures among the student body, help Access to HE students to cope successfully with the demands of the course and learn most effectively (Jones 2006). 
Group solidarity and mutual support were perceived by students in the study by Jones (2006) as significant factors in individual success.

Making particular choices in teaching, learning and institutional processes is a political act (Ball, 1987) involving the use of power to assert some values or practices at a particular point in time in a particular situation to the exclusion of others. For example, decisions taken by Access to HE tutors about when work should be handed in excludes other times/ dates, although students may try to negotiate these. Further, decisions taken by tutors and students are not taken in isolation but are also scrutinised by the gaze (Foucault, 1977) of more senior members of their college's organisational hierarchy and of the AVA awarding the Diploma for the course. Teachers and students have to comply with the values and choices held by this gaze. Power and micro-political processes are used by institutional members to negotiate or enact particular policies and values within the contexts of institutional structures. The last are the reified outcomes of past power struggles.

Power flows in any organisation or community (Foucault, 1986) and is accessible to all members of a community through the sources they can mobilise (Giddens, 1984), the social networks of which they have membership (Busher, 2006) and the negotiations they undertake. However, access to sources of power is unequally available in institutions because of the hierarchical distribution of authority (formally ascribed power) in a college (Hatcher, 2005). For example, teachers are given authority to organise the processes of learning with their students (Bourdieu and Passeron, 1977) allowing them to exercise control over their subordinates (Blase and Anderson, 1995). Ignoring hierarchy risks making discussion of the negotiations of community members appear more egalitarian than they are and may not accurately reflect the lived experiences of the members of those communities (Busher et al., 2007).

There are many sources of power (Giddens, 1984) linked to formal processes in organisations and to informal practices and personal knowledge (Busher, 2006) which are available to people to try to achieve their agenda and assert their values (Ball, 1987). Some influence the micro-political interactions of students (Benjamin, 2002). Others influence negotiations between students and tutors or between Access to HE tutors and college systems. For example, teaching and learning can only take place through students assenting to the processes chosen by their tutors, even if only tacitly. Through such processes and their interactions with other people in various social and institutional structures, students on Access to HE courses struggle to assert their agency and modify their identity and habitus as learners.

\section{Conceptualising communities of learners}

The term 'community' has a wide range of meanings but is unavoidable in trying to conceptualise how people coalesce together for particular purposes, such as learning on Access to HE courses. In this paper we draw a distinction between learning communities that are intentionally set up by institutions (Mangham, 2012, Andrews and Lewis, 2007) and communities of practice (Lave and Wenger 1991, Wenger 1998) that are emergent or naturally occurring (Mittendorf et al., 2005) amongst people coalescing to work together. The former emerges out of the literature on learning organisations (Senge, 2006, 
McGilchrist et al., 2004) and assumes the communities are carefully constructed by the activities of their leaders (Mitchell and Sackney, 2006) with the help of other members to construct particular cultures that engage members in purposeful work. This overlooks the importance of power as a constituent factor in the construction of communities (Hatcher, 2005, Handley et al., 2006).

There are important similarities and differences between intentional learning communities and emergent communities of practice. Both models of community share several similar features, such as emphasising the importance of collaborative cultures, differentiating between core and peripheral members, recognising the importance of boundaries both to demarcate communities and to act as semi-permeable membranes through which members of different communities interact, and recognising that communities often have overlapping membership. However, while individual communities of practice are said rather vaguely to relate to wider constellations of similar communities (Wenger, 1998, Holliday, 1999), learning communities are firmly placed within the boundaries of the institution to which they belong (Senge, 2006, McGilchrist et al., 2004). Emergent communities of practice are said to develop their own small cultures (Holliday 1999) while intentional learning communities (Mangham, 2012) are said to construct subcultures of their host institutions, as has already been discussed. In intentional learning communities hierarchically appointed leaders are viewed as essential in constructing cultures and practices of working and acting as gatekeepers. They exert control over new members (Lave and Wenger, 1991) by expecting them to conform to codes of practice and language, or to learn these, before they are permitted full membership of a group. In emergent communities of practice the role of formal leaders is vague although informal leadership is said to be exercised by existing core members of communities, the old lags (Lave and Wenger, 1991), who teach new entrants the ropes.

\section{Methodology and Methods}

The study took a social constructivist perspective (Lave and Wenger, 1991), using a linked case study design (Miles and Huberman, 1994) across seven FE Colleges in the East Midlands of England in 2012-2013. It used mixed methods to triangulate the perspectives of students on Access to HE course within and across colleges to enhance the trustworthiness of the study. It investigated the perspectives of marginalised adult learners, who were students on Access to HE courses, on their past and present learning experiences, on the transformation of their views of themselves as learners during the Access to HE courses, and on the impact on their learning of their socio-economic contexts and their relationships with their families, friends, Access to HE tutors and fellow students.

Subject to their ethical consent, all Access to HE course students in each college were invited to complete two questionnaires about their views of themselves as learners, one at the start of their course and one at the end. This instrument was intended to give a broad view of Access to HE students' perspectives and to complement the in-depth views gained from the student focus groups and concept maps, the last mainly being used as a trigger to stimulate students' positioning of themselves in relation to the Access to HE courses and the social contexts in which they lived and worked before the focus groups began. In each 
college, seven Access to HE students were invited to participate in focus group interviews on three occasions during the academic year, although the number of participants in each focus group tended to diminish during the year, raising questions about the representativeness of the views we were hearing at later stages in the study. The choice of students in each college for the focus groups was guided by our criteria for as wide a spread of students by social status and subject pathway within the Access to HE courses as possible but was, none the less, to some extent influenced by tutors. Access to HE tutors, too, were invited to take part in individual semi-structured or group interviews on two occasions during the year to provide an institutional perspective on the courses.

Data was analysed on a college by college basis as well as across colleges. We had 365 questionnaire responses (out of more than 700 possible replies) from the seven colleges/institutions in the Autumn 2012. Overall, $70 \%$ of respondents were female but in College 4 no men answered the questionnaire while in College $650 \%$ of the answers came from men. The quantitative data was analysed with simple descriptive statistics while the open-ended answers were scrutinized to generate numeric codes that would help to illustrate trends and patterns within the cohort of the study. The qualitative data from the interviews was audio-recorded, transcribed and analysed using a grounded approach (Corbin and Strauss, 2008) powered by NVivo to construct themes that reflected participants' own constructs of themselves and their contexts. The visual data from the concept maps, through which students could express their views of their transitions and transformations (Wall and Higgins, 2009), was analysed hermeneutically, an approach which took account of the views of Prosser (2006) and Pink (2006).

\section{Findings}

The distribution of the population for this study is consistent with QAA 2013 figures for the national population of Access to HE students. 52\% of the students were aged between 19 and 24 years, with $3.6 \%$ being aged 45 years or over. However, the study sample was less ethnically diverse than QAA 2013 figures (76\% white compared to 69\%). Only 10\% of the sample of this study had not previously worked, while $60 \%$ were currently employed, albeit mainly in low paid jobs. Nearly $12 \%$ of the respondents to the questionnaire did not have Level One qualifications while $18 \%$ did not have Level Two qualifications (GCSE). $70 \%$ of the respondents did not have Level Three qualifications (equivalent to ' $A$ ' level). The most popular Access to HE pathways in our study was Nursing and midwifery (54\%) followed by Social Science (22\%), Health Education (19\%) and Science (17\%).

The perspectives of students from the focus groups held during the Autumn term 2012 fall into four main themes: Discourses, significant others and the developing self; courses as arenas for student self-development; constituting a sense of community; facilitating learning through community. The different colleges in the study are referred to by number (e.g. Col 5) to keep them and their participants anonymous.

\section{Discourses, significant others and the developing self}


Students on the Access to HE courses had to negotiate a range of social and policy processes or discourses (Gee, 1999), in part because Access to HE courses are defined as full-time, to assert their agency, despite their relative powerlessness in many of the situations. Many of these students were married, had children, and worked as well, even if only part-time, 'because I can't afford to pay for [the course] without contributing. My husband works, but on his wage, we can't live' (Col 1).

Some employers were sympathetic to the pressures on the students and converted full-time jobs into part-time jobs or reduced the hours the students were working. One student was allowed by her employer to, 'drop down [from two days] to one day, [but] he's still paying me for two days and I'm paying him those days back in my spare time' (Col 3). However, other firms were not so sympathetic. 'I asked [for] my job to go part-time but they didn't allow it. So I had to leave and this made me ineligible for Job Seekers Allowance' (Col 5).

The impact on students of performativity and neo-liberal market economics (Jeffrey and Troman, 2012) were very visible. Agencies of the state seemed particularly unhelpful. In one case a student was refused benefit 'because I still live at home, they've judged my parent's income, whereas obviously I'm an adult and I support myself [and] I am desperately trying to seek a job' (Col 5). Although another student gained funding because, 'I got made redundant from my job' ( $\mathrm{Col} 3$ ), 'the Job Centre ... said that if a full-time job became available I'd have to quit the course and start the job' (Col 3). Colleges, too, constrained as they were by the guidelines of central government (BIS, 2010, 2012) and the college inspectorate about how colleges should be organised, were sometimes less than helpful. In one case a student was at first told, 'that I would be funded, but when I came for the enrolment [College] said, 'No'. So now I am struggling to pay the rest of the tuition fee ... it's really frustrating' (Col 2).

The financial constraints students faced were a burden to many of them although their desire for self-improvement also raised the skills of the British labour force, as central government policy encouraged (BIS, 2010) to generate economic growth. 'People like us, will probably be going on to get better jobs ... to make the economy better (Col 4). It was also enhancing their own cultural capital (Bourdieu, 1990) by improving their, 'careers so that we can be better people' (Col 4). However, students acknowledged that, 'without the degree and the things that come after, it's just ruled out' (Col 5). Their personal and sociopolitical contexts forced students into regimes of work that were hectic: 'I work full-time and I come here to school full-time and it's tiring and it can be hectic, and if you analyse it, it's almost impossible' (Col 6).

For students under these pressures, their families were a major source of practical support in students' struggles for education:

I get a lot of help from my mum with childcare because me and my husband both work and I'm here. So he's taking up the slack of other cooking and cleaning duties and the childcare (Col 3)

Families, as well as students' previous life experiences, were also an important source of inspiration for students, illustrating the importance of social capital (Bourdieu, 1990) to people. 'Now I've had my little boy, I want to show him that it's important to learn and what 
you can do when you apply yourself' (Col 7). 'If we don't do it [get to university], we're just wasting our life like again ... we've all like learnt from our past experiences' (Col 4).

Students thought the lack of free Access to HE courses, implemented since 2010 (BIS, 2010) was most unfair to people who were trying to study and work and not rely on state benefits. You've got to be on ... not just low income, but you've [also] got to be getting council tax benefit ... Basically you are penalised for being outgoing and doing what you are supposed to do in society ( $\mathrm{Col} 2$ )

In particular, several women students thought it essential to have free or grant aided Access to HE courses.

If I had to pay for [the course], I would have had to save this year to do it next year and I would have had to work as well because there was no way that would [cover] my nursery fees as well (Col 4)

\section{Courses as hierarchical but collaborative arenas for student self-development}

On the Access to HE courses the formal hierarchies of the college were less visible, in part perhaps because students thought 'most [tutors] treat us like adults I think. I've had a few problems with some' (Col 4). '[Tutors] understand that we're not school children who have no commitments outside college' (Col 1 ). This fits with the view of College cultures as collaborative, acknowledging the needs of adult students in them (Warmington, 2002, Jones, 2006). That students always referred to their tutors by the tutors' given names, without title, was, perhaps, an indicator of the relationships between them being collaborative but respectful.

Tutors tried to act as friendly facilitators and supporters of students. As one student commented about her course and her tutor:

I was quite worried that I would be lost and wouldn't have a clue, but after the support and having some feedback, I feel a lot more confident going forward (Col 5)

In part tutors' support arose from their expertise in their subject areas, 'making you sort of appreciate a subject and teaching it in a way that is both interesting and accessible' (Col 5), and the provision of a range of learning resources to students. In one college a student spoke of endless telephone calls with her tutor at home when developing her UCAS form (Col 4). In another, tutors seemed to provide an endless stream of tutorials if students, 'didn't understand anything in the lesson or [didn't] understand the assignment' (Col 7). Another resource was extensive use of formative assessment. 'Even now the teachers are still telling us how we should set out our assignments and helping us with things like referencing and it's been very helpful' (Col 5).

These supportive relationships served a critical function in helping students to be successful by seeing students', 'strengths and weaknesses and help[ing them] to develop from those' (Col 5). Further, tutors also cared for the whole person and not just the academic aspects of student development. 
When you're talking about families and past experiences of loss of loved ones and things like that ... [tutors] won't just like brush it away. They will have time for you to sit and discuss (Col 3)

However, the relationships between students and tutors were laden with power (Handley et al., 2006). The formal authority of the tutors (Bourdieu and Passeron, 1977) subtly indicated the unavoidably hierarchical nature of the relationships between tutors and students. It was tutors whom students notified when they could not attend the course for some reason. Tutors kept registers of student attendance as part of their functions as staff of a college. Tutors marked assignments and gave feedback to students on how to improve their work. These practices projected power over students (Blase and Anderson, 1995). Consequently, students always seemed to be aware of the hierarchical relationship between them and the tutors although tutors placed 'emphasis on independent learning and [gave students] enough support so that [they didn't] feel like [they]'re completely lost and like got nobody to turn to' (Col 5).

None the less, the Access to HE courses offered spaces (Paechter, 2004) for students to share with other like-minded people their aspirations for the future and the practicalities of developing their confidence, skills and knowledge to achieve those. It was an important space for developing confidence because students met, 'different people from different backgrounds and different behaviours' (Col 2). It helped them to learn who they were and what they were supposed to do (Col 2), developing their senses of identity through their interactions with others in particular situations (Giddens, 1991). In doing so students seem to have shifted their habitus (Bourdieu, 1990) and sense of agency (Wyn and White, 1998) through their interactions with others. As one student explained, '[it] helped me to find out who I am [so] I can be what I want because it's the choice that ... will take me to my destination ( $\mathrm{Col} 2$ ). The students' development of their identities helped them to reposition themselves within their society (Benjamin, 2002) and alter their interactions with others.

\section{Constituting a sense of community}

The Access to HE courses provided important sites for student transitions because their physical spaces helped students to develop social networks that facilitated their learning. 'We all talk to each other because we're all sat in a room together and sort of forced together' (Col 4). This sense of being part of a community had a dramatic effect on some students. 'It's absolutely changed my life and I've got complete focus now. I thought I'd just come here and be quite solitary' (Col 3). The nature of the community depended on the quality of relationships developed by the students among each other. 'We've got a really good mix and everybody's really focused and we're all wanting everybody to succeed and we're all supportive of each other' (Col 3). These collaborative cultures were purposeful and work-focused, constructing a community of practice (Wenger, 1998). 'I think in the classroom time everybody will work with everybody and then at lunch and break people like group with who they feel they gel with better' (Col 4). This illustrates that learning is a form of intellectual, physical, emotional and social work (Hodkinson, 2004) in which people use 
their resources and those of others, such as their teachers and colleagues, to construct new (social) artefacts of knowledge and skills and networks of relationships.

The development of a sense of community was facilitated by students' having common purposes for joining an Access to HE course. 'We all know why we're here. They [sic] want to get to university' (Col 6). 'It helps to all be in the same boat ... everybody here has either experienced education or has come to it fairly late' (Col 5). These purposeful communities generated collaborative cultures creating a mutual engagement in learning Wenger (1998).

In these emergent communities (Mittendorf et al., 2005) Access students were supportive of each other's endeavours. 'Everyone respects each other's opinions, respects why they're here ... [are] people that want to help me and I want to help them' (Col 6). It made it possible for people to make mistakes but learn from them without feeling threatened. 'Even though I was embarrassed, I wasn't like, "Oh my god. That was horrible". No one ... bullies or anything' (Col 7). This tolerance and trust of others is an important feature of collaborative cultures in learning communities (Andrews and Lewis 2007). Students in one college feared that breaching these norms would threaten the sense of community in their classes.

When your peers in your own class are like laughing at you [or] they're making sarcastic comments. I think we need to work on that (Col 4)

\section{Facilitating learning through a sense of community}

Students thought that sharing a sense of a community depended on positive interpersonal relationships. In one college a student noted, 'a very positive learning environment' (Col 1 ). In another college a student noted that, 'it helps having the same people around you obviously if you get on with them. We all kind of feel like we can depend on each other and support each other' (Col 5). It helped them to work successfully together: 'We do help each other with assignments' (Col 1), 'community spirit here definitely' (Col 5), and diminished people's individual sense of stress and worry. 'If you can ask other people about problems with an assignment or just the workload, then it takes a massive stress off, (Col 1).

The values which students held were made visible through the ways in which they worked. 'We don't often let people lag behind. If there's a problem, then we will help' (Col 1). In one college this led to, 'study groups in the library ... and get stuff done there, which is a good help' (Col 6). In another college, some students set up a group on Facebook, 'so we could post if we were at home saying, "Can anyone help me with this or does anyone know how I can get around doing this sort of work?"' (Col 3)

These views highlight a sense of responsibility as individuals and as a community, with people working to benefit other members of the community, not just themselves, through shared practices, artefacts, patterns of action and language. This reflects how Wenger (1998) and Holliday (1999) think people build small communities with their own distinctive cultures, yet linked to those of their host institution. In the liminal spaces (Bhabha 1994) of the Access courses, students who were initially strangers to each other and to the tutor built successful communities of learning practice. 


\section{Discussion}

Access to HE students discussed how their struggles with their socio-economic contexts helped them to recognise what they wanted to achieve in life. Their discussions showed the interplay between individual agency and identity, institutional structures and social circumstances (Wyn and White, 1998), including their families and friends, and how this led to their personal development. The development of the self was manifestly an on-going project (Giddens, 1991, Bauman, 2000, Brine and Waller, 2004). It was these struggles which gave Access students the motivations to return to formal education, even though it was an arena in which many of them had previously had little success. The asymmetrical nature of power was visible in many of these struggles where students felt they had limited power but, none the less, negotiated the best deals they could to meet their values and interests.

Students thought their Access to HE courses helped them to alter their identities as learners and develop their sense of agency as people, as did participants in the study of O'Donnell and Tobbell (2007). The cultures of their courses gave students a sense of community although these were imbued with asymmetrical power relationships (Hatcher, 2005). The collaborative cultures of the intentional learning communities (Mangham, 2012) which the tutors tried to construct on the courses were mediated by flows of power (Foucault, 1986), shaping how formally powerful people, such as course tutors acted as leaders or hosts (Derrida, 2000) and interacted with students and vice-versa. Students perceived their tutors as having formal power derived from their authority of office (Bourdieu and Passeron, 1977). They welcomed tutors organising the courses carefully and supporting them personally in their work of learning (Hodkinson, 2004). Tutors also played important boundary or peripheral roles for their courses, as models of communities of practice (Wenger, 1998) predict, negotiating with college leaders and AVAs on how to meet the demands of the curriculum and the regulatory contexts of college, course and wider policy frameworks, such as university deadlines for applications. It left them socially slightly apart from the students, but allowed them to project power to steer the community in directions to make learning as successful as possible.

The flows of power were not pathological constraints on the efficient working of the courses but part of the normal (political/ negotiative) processes of the course communities (Ball, 1987) about means and ways of learning and the construction of acceptable knowledge outcomes. For example, students negotiated work schedules with tutors to meet the constraints on their time and the requirements of the courses. Tutors projected power over students (Blase and Anderson, 1995) through their access to resources of knowledge which could help students pass the Access course, as well as regulatory or disciplinary power and powers of surveillance (Foucault, 1977) on behalf of their colleges and the AVAs giving Access to HE diplomas.

Students also asserted power in the relationships in the course communities, for example, by asking tutors for extensive help with developing aspects of their knowledge, drawing on the values made manifest in these communities to legitimate their requests. Flows of power also shaped how students began to construct emergent or naturally occurring (Mittendorf et al., 2005) communities of practice, sites and processes of informal learning to 
complement the formal learning spaces of their courses. In these emergent communities of practice, students negotiated with each other for help with learning and the logistics of attending their courses, using various forms of media to communicate, such as face to face contacts such as library study groups, emails, telephones, and online (Facebook) discussions. Most of the electronic communications excluded tutors suggesting Access students held their own sources of power and influence over the ways in which these sites developed, including their practices and values.

The spaces of the Access to HE courses (Paechter, 2004) were the arenas in which developed intentional learning communities, organised by the colleges and managed by the Access to HE course tutors, and emergent communities of practice, constructed by students. Both were focused on the enterprise of learning (Hodkinson, 2004). In the intentional learning communities, participants constructed collaborative cultures under the guidance of the tutors as formal leaders or hosts (Derrida, 2000). At the core of these cultures were values of respect for other people and collaboration in achieving the purposes of the courses. Collaborative cultures are said to be at the core of learning communities and communities of practice (Lave and Wenger, 1991, Wenger, 1998, Andrews and Lewis, 2007). The course cultures were subcultures of adult-learner oriented college cultures (Warmington, 2002) constructed collaboratively between tutors and students, albeit with asymmetrical power relationships of hierarchy (Hatcher, 2005) imbuing them. They helped students to become independent learners and meet the demands of their course validators and course providers.

Alongside and intermeshed with these intentional learning communities, developed emergent communities of practice constructed by the students to help each other develop as learners. The small cultures (Holliday, 1999) of these communities that emerged in the liminal spaces (Bhabha, 1994) of courses again appeared to be collaborative, perhaps reflecting those of the intentional learning communities with which they shared overlapping membership. In these communities, tutors were servants to the students, providing resources for learning in a multiplicity of ways but marginal or peripheral to the social and linked work processes of the groups. Further study needs to be undertaken to find out how power flows in these emergent communities of practice that seem similar to those investigated by Lave and Wenger (1991). As a result of their growing confidence and competence as learners, their enhancement of their social and cultural capital (Bourdieu, 1990), students began to shift the habitus (Bourdieu, 1990) with which they had entered the field of the Access to HE courses to become accomplished independent learners who could organise their own work.

\section{Conclusions}

While Access to HE has provided a valuable entry route into higher education for many mature students, there is a lack of up-to-date empirical research in England and Wales on the processes of transition and transformation that they experience. This study, based on Access students in seven colleges, albeit in only one region of England, is the largest of its kind in England and Wales since the year 2000 and addresses this dearth. It also takes account of how policy contexts have shifted since the studies of the earlier $21^{\text {st }}$ century. 
This study offers important insights into how Access to HE students pursued the project of the self (Giddens, 1991) shaping teaching and learning by negotiating with their teachers, although the teachers had greater access to sources of formal power, located in the institutional structures of teachers' and students' work than did the students. Students enhanced their social and cultural capital (Bourdieu, 1990) through being active participants in constituting their learning, working with teachers to build communities of practice (Wenger, 1998). These had purposeful, collaborative cultures based on trust and mutual respect, albeit with asymmetrical power relationships between participants (Hatcher, 2005). Despite students' power-invested relationships (Handley et al., 2006) with their tutors, the negotiations amongst students and teachers were viewed as legitimate and normal, not pathological aspects of teaching and learning that helped students to develop their sense of agency as citizens that went beyond the requirements of the tightly framed academic curriculum of their Access courses that formed part of the performative cultures of their colleges. The work of Watkins (2005) and Sebba and Robinson (2011) show similar cultures can also be applied in schools for students under the age of 16 years and will improve the success and quality of learning amongst those students.

The flows of power in the Access to HE course revealed two types of communities of practice, intentional learning communities (Mangham, 2012) established by the tutors, and emergent communities (Mittendorf et al., 2005) constructed by the students as their confidence grew in their abilities as learners and their sense of agency developed during their courses. The membership of these two types of community were heavily overlapped but in the latter the tutors were marginalised as providers of learning resources, whilst in the former they were leaders of learning.

Access to HE students' on-going struggles with their socio-political and economic contexts (Foucault, 1977) seemed only to have strengthened their resolutions to do something with their lives that contributed to the social well-being of their society. In doing so they also met government strictures about the need to improve the skills of the labour force. However, central government appeared to do little to help them financially in their endeavours.

\section{References}

Andrews, D. and Lewis, M. (2007) Transforming practice from within: The power of the professional learning community, in Stoll, L \& Louis, K (eds) Professional learning communities: Divergence, depth and dilemmas. Maidenhead: Open University Press. Pp.132-148

Ball, S. J. (1987) The Micro-politics of the school London: Methuen

Baumann, Z. (2000) Liquid Modernity. Cambridge: Polity Press

Benjamin, S. (2002) The micro-politics of inclusive education, Buckingham: Open University Press

Bhabha, H. 1994. The location of culture. London: Routledge

Blase, J. and Anderson, G. L. (1995) The Micro-politics of Educational Leadership: From Control to Empowerment, London: Cassell.

Bourdieu, P (1990) The logic of practice, tr. Richard Nice Cambridge: Polity Press 
Bourdieu, P. and Passeron. J-C. (1977) Reproduction in education: Society and culture. London: Sage.

Brine, J. and Waller, R. (2004) Working class women on an access course: risk, opportunity and (re)constructing identities, Gender and Education, 16 (1) 97-113

Burke, P. J. (2007) Men Accessing Education: Masculinities, Identifications and Widening Participation, British Journal of Sociology of Education, 28(4) 411-424.

Busher, H (2006) Understanding Educational leadership: People, power and culture, Buckingham: Open University Press

Busher, H., Hammersley-Fletcher, L., and Turner, C. (2007) Making sense of middle leadership: Community, power and practice, School Leadership and Management 27 (5) 405-422

Corbin, J., and Strauss, A. (2008) Basics of qualitative research: techniques and procedures for developing grounded theory 3rd ed. Los Angeles, Calif. \& London: Sage,

Crossan, B., Field, J., Gallacher, J., Merrill, B. (2003) 'Understanding Participation in Learning for Non-traditonal Adult Learners: learning careers and the construction of learning identities', British Journal of Sociology of Education, 24 (1) 55-67.

Department for Business, Innovation and Skills (BIS) (2010) Further Education - New Horizon: Investing in Sustainable Growth, Available Online at: http://www.bis.gov.uk/assets/biscore/further-education-skills/docs/s/10-1272-strategyinvesting-in-skills-for-sustainable-growth.pdf

Department for Business, Innovation and Skills (2012) Government response to 'Students at the heart of the system' and 'A new regulatory framework for the HE sector', Available online at: http://www.bis.gov.uk/assets/biscore/higher-education/docs/g/12-890government-response-students-and-regulatory-framework-higher-education Derrida, J. (2000) Of Hospitality, Stanford Ca: Stanford University Press Field, J., Merrill, B., and Morgan-Klein, N. 'Researching Higher Education Access, Retention and Drop-Out through a European Biographical Approach: Exploring similarities and differences within a research team', European Society for Research on the Education of Adults, Sixth European Research Conference, University of Linköping, 23-26 September 2010. Foucault, M. (1977) Discipline and Punish: The Birth of the Prison, trans. A. Sheridan, London: Allen Lane

Foucault, M. (1976) Truth and Power, in C. Gordon (ed) (1980) Power / Knowledge: Selected interviews and other writings by Michel Foucault, 1972-1977 New York: Pantheon Books Foucault, M. (1986) Disciplinary power and subjection in S. Lukes, (ed) (1986) Power, Oxford: Blackwell.

Gee, J. P. (1999) An introduction to Discourse Analysis: Theory and Method London: Routledge, pp. 2-18. In A. Holliday, M. Hyde, \& J. Kullman (Eds) (2010) Intercultural communication, an advanced handbook, $2^{\text {nd }} E d$. London: Routledge. p.75

Giddens, A. (1991) Modernity and self-identity: Self and society in the late modern age, Cambridge: Polity Press.

Giddens, A. (1984) The Constitution of Society, Cambridge: Polity Press.

Handley, K., Sturdy, A., Fincham, R. \& Clark, T. (2006) Within and Beyond Communities of Practice: Making Sense of Learning through Participation, Identity and Practice, Journal of Management Studies, 43, 641-653

Hatcher, R. (2005) The distribution of leadership and power in schools, British Journal of Sociology of Education, 26 (2) 253-267 
Hodkinson, P (2004) Research as a form of work: Expertise, community and methodological objectivity, British Educational Research Journal, 30 (1) 9-26

Hodgkinson, C. (1999) The triumph of the will: an exploration of certain fundamental problematics in administrative philosophy, in: P. T. Begley \& P. E. Leonard (Eds) The values of educational administration London: Falmer Press pp.7-22

Holliday, A. (1999) Small cultures. Applied Linguistics, 20, 237-264.

Holliday, A. (2010) Introduction. In A. Holliday, M. Hyde, \& J. Kullman (Eds) (2010)

Intercultural communication, an advanced handbook 2nd Ed. London: Routledge. pp.1-6

Hollis, M (1985) Of masks and men in M. Carrithers, S. Collins, and S. Lukes, (eds) (1985) The category of the person: Anthropology, philosophy history Cambridge: Cambridge University Press pp.217-233

Jeffrey, B. and Troman, G. (2012) Introduction, in Jeffrey, B. and Troman, G. (Eds) Performativity across UK education: ethnographic cases of its effects, agency and reconstructions, Painswick: E\&E Publishing. pp.1-5

Jephcote, M., Salisbury, J. and Rees, G. (2008) Being a teacher in further education in changing times, Research in Post Compulsory Education, 13 (2), 163-172.

Jones, K. (2006) Valuing diversity and widening participation: The experiences of Access to Social Work students in further and higher education, Social Work Education, 25 (5), 485 500.

Kearney, C (2003) The Monkey's mask: Identity, memory, narrative and voice, Stoke-onTrent, Trentham Books

Lave, J. and Wenger, E. (1991) Situated learning: Legitimate peripheral participation Cambridge: Cambridge University Press.

MacBeath, J and MacDonald, A (2000) Four dilemmas, three heresies and a matrix, in K.A. Riley and K.S. Louis (eds) Leadership for change and school reform, London: Routledge

Falmer pp.13-29

MacGilchrist, B. Myers, K and Reed, J (2004) The Intelligent School, 2nd Edn London: Sage Mangham, C. W. (2012) A combined framework for investigating communities of practice and the function of the learning organization: a case study of an industrial training unit in the United Arab Emirates Leicester: University of Leicester

Miles, M. B, and Huberman, M. (1994) Qualitative Data Analysis: An Expanded Sourcebook, CA., Thousand Oaks: Sage Publications Inc

Mitchell, C. and Sackney, L. (2006) Building schools, building people: The school principal's role in leading a learning community, Journal of School Leadership, 16: 627-640.

Mittendorf, K., Geijsel, F., Hoeve, A., Laat, M. D. \& Niewenhuis, L. (2005) Communities of practice as stimulating forces for collective learning Journal of Workplace Learning, 18, 298312

O'Donnell, V. L. and Tobbell, J. (2007), The transition of adult students to higher education: legitimate peripheral participation in a community of practice?, Adult Education Quarterly, 57 (4), 312-328.

Paechter, C. (2004) Space, Identity and Education Pedagogy, Culture and Society, 12 (3) 307 Pink, S. (2001) Doing visual ethnography. London: Sage publications

Parry, G. (1996) Access education in England and Wales 1973-1994: from second chance to third wave, Journal of Access Studies, 11, 10-33.

Prosser, J. (2006) Image-based research: a sourcebook for qualitative researchers. London: RoutledgeFalmer 
Quality Assurance Agency (2013) Key Statistics

http://www.accesstohe.ac.uk/AboutUs/Publications/Documents/Key-statistics-2013.pdf Sebba, J. and Robinson, C. (2011) Evaluation of UNICEF UK'S Rights Respecting Schools Award paper presented to British Educational Research Association Annual Conference, Institute of Education, University of London, London UK, 7-9 Sept 2011

Senge, P. M. (2006) The Fifth Discipline, New York: Currency Doubleday.

Smyth, J., Dow, A., Hattam, R., Reid, A. and Shacklock, G. (2000) Teachers' Work in a Globalising Economy, London: Falmer Press.

Wall, K. \& Higgins, S. (2009) Pupils' views of Templates: A visual method for investigating children's thinking, ESRC Seminar, Leicester University, Jan 2009

Warmington, P. (2002) Studenthood as Surrogate Occupation: Access to HE Students' Discursive Production of Commitment, Maturity and Peer Support, Journal of Vocational Education and Training, 54 (4) 583-600.

Watkins, C. (2005) Classrooms as learning communities: a review of research, London Review of Education, 3 (1) 47-64

Wenger, E. (1998) Communities of Practice: Learning, Meaning, and Identity New York: Cambridge University Press.

Wyn, J. and White, R. (1998) Young people, social problems and Australian youth studies, Journal of Youth Studies 1(1) 23-38. 